\title{
Maurice Blanchot E O SilÊNCio da Palavra ${ }^{1}$
}

\author{
Eleonora Frenkel \\ Universidade Federal de Santa Catarina \\ eleonora.frenkel@gmail.com
}

\begin{abstract}
Resumo: Maurice Blanchot nos apresenta uma concepção de linguagem a partir da "inquietante maravilha do ato de nomear": a palavra manifesta a ausência daquilo que nomeia, ela é a materialidade vazia de uma anterioridade inapreensível. Que grande desafio se abre para a literatura moderna quando se ocupa justamente do esvaziamento da linguagem, quando se pergunta sobre esse nada inapreensível com o qual se faz. A literatura é linguagem. Uma linguagem que se coloca em questão, que se pergunta sobre suas possibilidades e que faz de suas impossibilidades sua maior busca. Por isso dirá Blanchot que a literatura tende para o silêncio, ela se move em direção e para além de seus limites. Embora se faça com a palavra, explora seu silêncio. O impossível apaixona a poesia e ao inventar os modos de realizar o irrealizável, ela cria novos possíveis e se refaz num devir constantemente renovável. Esse é o espaço da imaginação e sua dimensão política latente.
\end{abstract}

Palavras-chave: literatura; linguagem; experiência.

Abstract: Maurice Blanchot brings a conception of language issued from the disturbing act of giving names: the word means the absence of what is named; it is the empty materiality of an inapprehensible anteriority. A great challenge for modern literature begins when it worries with the emptying of language, when it wanders about that inapprehensible nothing with which it is made. Literature is language. A language which arises itself in question and asks about its possibilities and which has impossibility as its main research object. That is why Blanchot will say that literature is prone to silence, it moves towards and beyond its boundaries. Even though literature is made with words it explores silence. The impossible fascinates poetry when it invents the way of accomplishing that which is not possible to accomplish, it creates new possibles and makes itself again in a constant and renewable. That is the locus of imagination and its latent political dimension.

Keywords: literature; language; experience.

Silêncio. Eu te conheģo por ouvir dizer Blanchot. A loucura do dia, 1949

A busca do ABSOLUTO

Na pintura de René Magritte que leva o título de "A busca do absoluto" (1964), vemos em primeiro plano uma imensa árvore em forma de folha que nos provoca um estranho fenômeno de desrealização: ela tem as dimensões de uma árvore e o aspecto de uma folha, como se essa pequena parte que compõe o todo se somando a muitas outras

\footnotetext{
${ }^{1}$ Este texto foi inicialmente pensado para ser apresentado na $46^{a}$. edição do Café Philo, organizado pelo Professor Pedro de Souza e promovido pela Secretaria de Cultura da UFSC e Aliança Francesa, no dia 19/09/2012, na Fundação Cultural Badesc, Florianópolis/SC.
} 
folhas iguais a ela, de repente viesse a superar esse todo ou a se tornar ele mesmo. Ao lado dessa estranha presença, nos deparamos com uma esfera branca, levemente acinzentada por uma sombra, sutilmente clareada pela luz direta. É uma rocha? Parece perfeita demais para sê-lo... Entre a folha e a esfera, em tamanho reduzido, de costas, duas figuras humanas, quem sabe lavradores com sua enxada. Eles são vistos à distância num exercício plástico que é também bastante explorado por Alberto Giacometti em seus desenhos e esculturas. Em torno, há um imenso vazio de céu e de terra que se ocupa com esses quatro elementos (os homens, a folha, a esfera). Eles preenchem o todo da pintura, fecham esse quadro como um espaço finito. Mas, afinal, que totalidade se preenche aqui? $O$ que significa tudo isso? O que essa composição nos diz? TALVEZ tantas coisas e NADA em definitivo? E parece que é assim que ficamos: com suposições sem fim...

Em suas "reflexões sobre o surrealismo", ${ }^{2}$ Blanchot dirá que esse movimento é "uma dessas tentativas pelas quais o homem pretende se descobrir como totalidade". É um movimento que está à procura de "um fato absoluto, em que o homem se manifeste em todas as suas possibilidades”. A primeira questão que deve nos chamar a atenção aqui é que essa totalidade se percebe inacabada e justamente por se ver inacabada é que ela poderia ser fugidiamente apreendida em um momento privilegiado. Como se fosse um instante de totalidade que no próximo instante já se vê incompleto, de modo que ela [a totalidade] se torna um fim inalcançável. A segunda questão que nos chama a atenção é a aparição da dimensão da impossibilidade. A percepção de sua existência não a torna menos desejada. Não se desiste do impossível, mas se almeja explorá-lo.

Um dos recursos utilizados pelo surrealismo nessa busca pelo "fato absoluto" é a escrita automática, esse exercício pelo qual justamente TUDO é possível, em que a linguagem do sonho pode se tornar real, em que a linguagem pode não ser discurso inteligível, em que o silêncio pode falar. No Segundo Manifesto de André Breton, o fato absoluto se apresenta como um ponto em que real e imaginário deixam de ser considerados contraditórios. E essa é uma terceira questão que devemos destacar: a confusão entre os limiares ou a dissolução das fronteiras estanques: do mesmo modo que real e imaginário se tornam indiscerníveis, possível e impossível se misturam, morte e vida se completam. E é nessas zonas de indistinção que operam muitas das reflexões de Blanchot.

2 Blanchot. A parte do fogo, 1949/1997. 
Bem, há ainda uma quarta questão fundamental e, talvez, o ponto de partida de toda essa reflexão. Ela exige encarar a complexidade do conceito de absoluto. ${ }^{3}$ Uma complexidade que, por certo, será abordada aqui de modo precário e apenas inicial. O Absoluto, num primeiro momento, estaria associado ao Todo, ao Uno, a Deus. Entre as diversas definições apresentadas ao longo da história da filosofia, Blanchot dialoga com a de Hegel, segundo a qual o Todo se realizaria pela expressão máxima da Razão para a qual caminha a História. A consciência e a consciência-de-si do sujeito conduziriam à efetivação do Espírito Absoluto. Esse seria o rumo da realização do possível do homem (que se concretiza na figura do trabalhador) e da vida em sociedade (organizada pelo Estado). O Absoluto seria, então, um "trabalho da história", resultante da vida industriosa e cidadã (na perspectiva de Hegel).

A partir disso, podemos tentar entender dois momentos em que Blanchot resgata a reflexão de Hegel apresentada em seu curso de Estética. Hegel diz: “A arte é, para nós, coisa passada". Blanchot se pergunta o que teria querido dizer Hegel naquela ocasião, chamando a atenção ainda para o fato de que um século depois, André Gide também afirmaria: "Durante um largo tempo, a obra de arte está fora de questão". Blanchot diz, ainda, é curioso que essas afirmações tenham sido feitas diante da evidência de que a literatura, as artes plásticas, a música jamais deixaram de produzir obras consideráveis. De que se trataria, então, essa consideração a respeito de um pretenso fim da arte?

Em O espaço literário, a resposta de Blanchot é: Hegel estaria dizendo...

\begin{abstract}
...apenas isto, precisamente: que a partir do dia em que o absoluto se tornou, conscientemente, trabalho da história, a arte deixou de ser capaz de satisfazer a necessidade de absoluto: tudo o que ela tinha de autenticamente verdadeiro e vivo pertence agora ao mundo e ao trabalho real do mundo. ${ }^{4}$
\end{abstract}

Ou seja, a arte seria coisa do passado porque teria deixado de se ocupar do Absoluto que caberia, agora, ao "mundo real". Em "O desaparecimento da literatura", Blanchot completa essa leitura da perspectiva de Hegel:

A arte não é mais capaz de portar a necessidade de absoluto. O que conta absolutamente, doravante, é a realização do mundo, a seriedade da ação, a tarefa da liberdade real. A arte só

\footnotetext{
3 Ver: J. Ferrater Mora. “Absoluto”, Dicionário de Filosofia (tradução de Maria S. Gonçalvez et al. SP: Loyla, 2004).

4 Blanchot. O espaço literário, p. 233.
} 
está próxima do absoluto no passado, e é apenas no Museu que ela ainda tem valor e poder. Ou então, desgraça ainda mais grave, ela decai em nós até tornar-se simples prazer estético, ou auxiliar da cultura. ${ }^{5}$

Bem, Blanchot parece concordar com Hegel quanto ao desaparecimento da arte. Em O livro por vir, ele afirma: "a literatura vai em direção a ela mesma, em direção à sua essência, que é o desaparecimento". ${ }^{6}$ No entanto, não porque ela tenha deixado de corresponder ao absoluto, mas justamente porque continue em sua busca. A questão é a operação realizada sobre esse conceito de absoluto, que se vê esvaziado, que deixa de ser o Todo, a Totalidade, a Unidade, para ser o vazio e a impossibilidade. A arte desaparece é como possibilidade de totalização para se fazer em busca de sua impossibilidade. Roland Barthes dirá que "a modernidade começa com a busca de uma Literatura impossível". ${ }^{7}$ Qual seja: a partir do momento em que o absoluto se percebe um fim inalcançável ou um vazio inverificável, é esse problema que a poesia quer enfrentar. Ela também deixa de se perceber como possibilidade de presentificação e passa a perseguir o risco do seu próprio desaparecimento.

Podemos recorrer ao verbete "Absoluto", de Georges Bataille, para pensar esse outro modo de compreender o conceito. Diz ele: “O absoluto é a soma de todas as compensações para as misérias humanas". ' O homem inventou Deus para que suas imperfeições fossem julgadas por algo superior a ele. Esse ser supremo é tão potente quanto inexistente. E é justamente sua impossibilidade de apreensão o que lhe dá o poder maior de julgar e perdoar. "O absoluto é poderoso porque é perfeitamente vazio: é graças a essa característica que representa a perfeição da verdade". ${ }^{10}$ Quer dizer, a totalidade, a verdade, a perfeição aparecem como aspirações improváveis, inverificáveis e, portanto, irrefutáveis. O absoluto não possui essência ou sua essência é o vazio, de modo que a arte, ao buscá-lo, move-se em direção ao inapreensível.

É nesse sentido que Blanchot afirma que uma das tarefas desenvolvidas pelo surrealismo é "que a literatura realize sua própria irrealidade". ${ }^{11} \mathrm{Um}$ dos desafios aos quais

\footnotetext{
${ }^{5}$ Blanchot. O livro por vir, p. 257.

${ }^{6}$ Op. cit, p. 285.

${ }^{7}$ Barthes. O grau zero da escritura, p. 138.

8 Encyclopaedia Acephalic, Comprising the Critical Dictionary \& Related Texts (Edited by Georges Bataille). Disponível em: http://athemita.files.wordpress.com/2007/04/encyclopaedia-acephalica.pdf

9 "The absolute is the sum of the compensations for human wretchedness"

10 "The absolute is powerful because perfectly empty: it is thanks to this characteristic that it represents the perfection of truth"

${ }^{11}$ Blanchot. A parte do fogo, p. 292.
} 
se dedica é como tornar o absoluto (o vazio, o irrealizável, o silêncio) uma linguagem? Ou: como fazer a linguagem calar? Ou, ainda, como criar o silêncio na palavra?

\section{SILÊECIO... aqui vem a palavra}

Em uma das narrativas breves de Clarice Lispector, lemos sobre o silêncio onipresente, esse algo que não é nada e do qual não podemos escapar, que nos espreita e nos toma desapercebidos. Inútil querer fugir, corremos o risco de encontrá-lo "ao atravessar a rua no meio das buzinas dos carros", ou "entre uma gargalhada fantasmagórica e outra", ou "depois de uma palavra dita", ou, o que é mais grave, “às vezes no próprio coração da palavra”.

O silêncio no coração da palavra de que nos fala a narrativa de Clarice, nos remete a uma reflexão importante a respeito da linguagem em Blanchot: a palavra não representa ou torna presente uma coisa/um objeto que lhe seria anterior e do qual seria sua expressão. A palavra não conteria esse precedente, ela seria, ao contrário, a manifestação do afastamento daquilo que ela nomeia (a palavra afasta a coisa para significá-la). Nesse sentido, a linguagem é a ausência da coisa; a palavra é uma falta fundamental, é um esvaziamento, é uma nulidade, é um fantasma. ${ }^{12}$ Ela é o estado de perda da coisa inicial que designa, ela é a morte desse nomeado e, ao mesmo tempo, é aquela que lhe concede nova vida.

Se toda palavra comporta uma ausência ou, se falar é substituir uma presença por uma ausência, o silêncio, como grande manifestação do nada, seria o mais alto grau dessa ausência. O silêncio está no coração da palavra. Ele é como um sopro inaudível que explicita o espaço vazio do significado que toda palavra quer ter. Ela quer significar, mas o faz sempre de modo precário. Isso abre uma daquelas zonas de indistinção nas quais opera o pensamento de Blanchot: ao mesmo tempo em que a palavra aparece como algo inapreensível, como uma "brancura vazia", como um "envoltório de um nada", ela é um nada extremamente fecundo, um NADA que pode ser TUDO.

Vejamos, por exemplo, a ideia de que eu "digo: essa mulher" e de que "para que eu possa dizer: essa mulher, é preciso que de uma maneira ou de outra eu lhe retire sua realidade de carne e osso, que a torne ausente e a aniquile". ${ }^{13}$ Ou seja, a palavra mulher mata a mulher de carne e osso, afasta-a de nós, torna-a um objeto intangível, esvazia-a enquanto

12 Op. cit. p. $78 ; 80$.

13 Op.cit. p. 310-311. 
ser. No entanto, no espaço em que essa palavra surge, ela cria uma personagem mulher que pode ser qualquer coisa, cujas potencialidades são infinitas. A ausência de significado único se desdobra em uma multiplicidade de significações.

Podemos pensar em outra narrativa de Clarice Lispector, Um sopro de vida (1977), em que o personagem Autor cria sua personagem Ângela Pralini. Ela é inventada na palavra, ela "parte da linguagem à existência", "ela não existiria se não houvesse palavras". ${ }^{14}$ Ela não possui uma referência anterior, uma mulher de carne e osso à qual se possa remeter. E é dessa falta, dessa ausência, que surgem todas as suas possibilidades de ser no espaço da ficção. Ela é uma realidade inventada ou uma irrealidade que se faz possível. A palavra cria a coisa como ausência e ao mesmo tempo dá existência ao que não existe. Mais uma vez Clarice Lispector, em $A$ paixão segundo G.H., nos ajuda quando escreve: já que "viver não é relatável", é preciso fazer a palavra para poder criar o que aconteceu.

A escritura de Clarice é um desdobramento daquela que se abre com diversos escritores em meados do século XIX. A questão que passa a ocupar alguns poetas é justamente a da palavra, qual seja, a poesia passa a se perguntar sobre a matéria com a qual se faz, passa a tornar-se ela mesma sujeito-objeto de suas criações (A linguagem desaparece como instrumento para se tornar sujeito - a escritura se far, ela é sujeito de si mesma). Em Hölderlin, diz Blanchot, o poema passa a ser "essencialmente poema do poema". A literatura se interroga e se pergunta sobre as possibilidades da linguagem. Se o silêncio constitui a linguagem e se essa constituição coloca em risco a literatura, é esse risco que se irá correr. Segundo Blanchot, Mallarmé e Cézanne promovem uma "experiência essencialmente arriscada em que a arte, a obra, a verdade e a essência da linguagem são questionadas e se põem em risco". Nessa experiência "o poeta se torna o inimigo amargo da figura do poeta". Percebem-se a impotência da fala, as impossibilidades da representação e do significado unívoco, as dificuldades da comunicação e os impasses da interpretação.

Com o qual voltamos àquele desafio de tornar o absoluto uma linguagem. Blanchot dirá "a literatura pretende fazer da linguagem um absoluto e reconhecer nesse absoluto o equivalente do silêncio". ${ }^{15}$ O silêncio colocaria uma das maiores dificuldades para essa inquietante maravilha do ato de nomear. Se a tarefa da linguagem é nomear a ausência da coisa, como ela pode nomear a ausência da ausência? Bataille dirá que entre todas as

\footnotetext{
${ }^{14}$ Lispector. Um sopro de vida, p. 83.

15 Op. cit. p. 67.
} 
palavras, "silêncio" é a mais perversa, pois "ela é a própria garantia de sua morte" ${ }^{16}$ É a paixão impossível de sua nomeação que ocupará a tantos escritores.

Blanchot diz que Mallarmé jamais se libertou da impossibilidade de nomear o silêncio, que "foi em vão que [ele] pediu à brancura da página... uma representação material do silêncio". Os espaços em branco no poema "Um lance de dados" (1897) propõem um esforço para criar os vazios contidos nas palavras e as esperas em seus deslocamentos e contatos. O movimento da escritura inclui o silêncio, procura dar a ele uma materialidade. Esse e outros recursos tipográficos levados a cabo no poema impõem fortes rupturas no modo de fazer poético vigente até então. Impõem justamente uma saída dos possíveis definidos pela literatura naquele entorno, uma transgressão das normativas estabelecidas no campo da literatura.

Blanchot identifica em Joubert uma "presença antecipada de Mallarmé”. Destaca um fragmento dos Carnês (8 de junho de 1823) onde se lê: "Espaços...eu diria quase...imaginários, de tal modo sua existência é...". O exemplo mostra justamente a exploração de recursos capazes de suspender a palavra, de criar "silêncios que modelam o ar", de reter a palavra para que ela escape, para que ela deixe de ser evidente e se torne perturbadora. ${ }^{17}$

Perturbar seria aqui um modo de tirar da zona de conforto da compreensão, um modo de provocar a moléstia de se perceber incapaz de conviver com aquilo que não se pode entender. E com isso passamos a algumas considerações sobre a desoperação da linguagem provocada na literatura, mas, antes disso, vale a pena destacar ainda outro aspecto da criação do silêncio que se promove no texto literário.

Segundo Blanchot, a escritura é um movimento constante, a fala é incessante; "O poema - a literatura -“, diz ele, "parece vinculado a uma fala que não pode interromper-se porque ela não fala, ela é”. E “o poeta é aquele que ouviu essa fala, que se fez dela o intérprete, o mediador, que lhe impôs o silêncio pronunciando-a" ${ }^{18}$ O domínio do escritor consiste em fazer o recorte, em silenciar essa fala no instante em que decide o que será dito e o que não será. Parar de escrever se revela um trabalho de maior acuidade do que o de iniciar a escrita. Ao efetuar essa interrupção, o poeta torna o texto finito, cria um espaço finito em que ele será contido, embora essa finitude se mantenha constantemente em aberto (a cada nova leitura, no mínimo, ele ganhará novos desdobramentos).

\footnotetext{
16 Bataille. A experiência interior, p. 24.

17 Blanchot. O livro por vir, p. 80.

18 Blanchot. O espaço literário, p. 29.
} 
A partir dessa compreensão, o tom da obra designa a particularidade do silêncio criado por aquele que escreve, por aquele que possui a decisão de emudecer e que, ao fazêlo, cria um arejamento ou conforma os espaços vazios que irão circunscrever aquilo que fala. $^{19}$

Podemos pensar, por exemplo, em uma fala do escritor Mario Bellatin a respeito do romance: Flores e de seu método de escrita. Ele diz que o texto apresenta um "silêncio construído" que ele explica da seguinte maneira: num primeiro momento, quando começa a escrever, "enche demasiadamente as coisas", transborda do que se supõe ser a excelência, a prerrogativa ou a qualidade que pode ter um escritor de ter uma linguagem muito florida ou de criar muitos personagens. No entanto, o momento em que se sente mais escritor não é esse, mas sim quando faz o trabalho inverso, quando destrói, quando faz silêncios, quando cria vazios eloquentes.

Também é interessante pensar nas anotações deixadas por Clarice Lispector no processo de organização do romance: $O$ Lustre. O que mais se destaca é aquilo que ela pretende tirar da narrativa: tirar o excesso de adjetivos, tirar as palavras modernas, tirar o tom falsamente inocente, desfazer as analogias, criar vazios nos diálogos. Parece ser um processo de "limpeza", de enxugamento, de esvaziamento ou de silenciamento do texto. Algo como: criar o que não se quer dizer para dar forma ao que se quer dizer...

Nesse sentido, Blanchot diz que "um escritor é aquele que impõe o silêncio a essa fala [infinita, que é a escritura], e uma obra literária é, para aquele que sabe penetrar nela, uma preciosa morada de silêncio, uma defesa firme e uma alta muralha contra essa imensidade falante que se dirige a nós, desviando-nos de nós". ${ }^{20}$ Ou seja, ler um texto é também escutar seus silêncios, é perceber qual é o "silêncio particular" que nos atinge em cada leitura.

\section{PALAVRA em estado de FUGA... TRAMPOLIM}

Voltemos à questão da desoperação da linguagem provocada na literatura moderna. Blanchot nos solicita: "Admitamos que a literatura comece no momento em que a literatura se torne uma questão", ${ }^{21}$ ou seja, consideremos que a literatura é literatura quando coloca

\footnotetext{
19 Op. cit, p. 18.

${ }^{20}$ Blanchot. O livro por vir, p. 321.

21 Op. cit., p. 292.
} 
em xeque a linguagem que a constitui. Já vimos que parte dessa reflexão está na consideração da linguagem como manifestação da ausência daquilo que nomeia. A palavra interpõe uma distância entre nós e a coisa que ela significa. Pois bem, a palavra literária teria ainda a particularidade de ampliar essa distância e de tornar mais inalcançável o objeto ao qual se refere. E ela o faz através de um abalo de toda "sedimentação de significações confortáveis", 22 quer dizer, ela impede que o sentido se estabilize, que o significado se associe facilmente. É a isso que se chamaria da palavra em estado de fuga daquilo que ela significa.

A ideia é criar tal distância entre a palavra e o que ela nomeia que permita uma significação livre de qualquer referência concreta. O grande privilégio da linguagem não seria "expressar um sentido", mas sim criá-lo, ou seja, fazer literatura não seria comunicar um sentido pré-estabelecido e sim inventar novas significações, fugir do que está dado de antemão. Blanchot menciona a fala de Jean Starobinski em sua leitura de Rousseau, segundo a qual:

'A palavra autêntica é uma palavra que não se restringe à imitação de um dado preexistente; ela é livre para deformar e inventar, com a condição de permanecer fiel à sua própria lei. Ora, essa lei interior escapa a todo controle e a toda discussão. A lei da autenticidade não proíbe nada, mas nunca está satisfeita. Ela não exige que a palavra reprodura uma realidade prévia, mas que produza sua verdade, num desenvolvimento livre e ininterrupto.'.23

A palavra poética é livre para ser deformação. A lei que a rege permite que seja torta, que não se atenha à retidão. A literatura se apresenta como um convite à transgressão e almeja levar a linguagem à sua ruína. Blanchot dirá: “A poesia, pela ruptura que produz, pela tensão insustentável que cria [entre os elementos da linguagem], só pode desejar a ruína da linguagem, mas esta ruína é a única chance que ela tem de se realizar". ${ }^{24}$ A literatura rompe com nossas relações naturalizadas com a linguagem e, ao fazê-lo, esvazia suas possibilidades comunicativas. Ela está aquém ou além das exigências da comunicação de sentido, ela cria um espaço onde a legalidade da linguagem é o que escapa à lei, é o que ultrapassa as normas do poder.

Como se opera esse "desafio técnico" de ampliar o abismo da referencialidade e da atribuição de significado?

\footnotetext{
22 Op. cit., p. 73.

23 Blanchot. O livro por vir, p. 65.

24 Blanchot. A parte do fogo, p. 58.
} 
Mallarmé, por exemplo, o faz pela criação de um estado de fuga, de negação, muito mais do que afirmação de imagens. Quando a imagem está a ponto de se cristalizar, a frase se desloca. Por outro lado, também procura atrair o olhar sobre as próprias palavras, para desviar esse olhar da coisa de que falam, de modo que os sons, o ritmo, o atrito entre elas passam a ser mais importantes do que as atribuições correntes da palavra que designa um objeto. Blanchot fala ainda da criação de "imagens inquietas, mais atos que formas, mais transições de sentidos que expressões". O movimento da escritura, a sucessão ritmada, o espaçamento, a difusão se destacam sobre as possibilidades de figuração das palavras e da narrativa.

O movimento surrealista, por sua vez, ampliou esse abismo ao desinstrumentalizar a linguagem, ao invés de fazer uso dela para expressar um conteúdo, ela se torna sujeito dela mesma, ela ganha liberdade na escrita automática ao se confundir com o "pensamento" do homem, ao fazer o silêncio do inconsciente irromper na linguagem. ${ }^{25}$ Com esse recurso se suspendem as "obrigações da reflexão", se combate o discurso, se tira dele "todo o direito de significar alguma coisa". "A linguagem parece ser não apenas sacrificada, mas também humilhada". Mas esse sacrifício impulsiona a libertação das palavras, que "não dependem mais exclusivamente das coisas que expressam", mas que "agem por conta própria, brincam e, como diz Breton, 'fazem amor'.,"26

Walter Benjamin já dissera em seu texto sobre o surrealismo que o grupo envolvido nesse movimento "levou a 'vida literária' até os limites extremos do possível" e explodiu o domínio da literatura de dentro. Quer dizer, a destruição levada a cabo por essas vanguardas artísticas provocou uma desoperação da linguagem como discurso lógico e como instrumento de expressão, promoveu uma subversão dos modos de fazer poéticos consolidados e, com isso, reabriu as possibilidades de criação.

A literatura moderna se coloca, então, a tarefa de "afastar de nós a linguagem que nos parece às vezes tão próxima": ${ }^{27}$ desfamiliarizar, desnaturalizar, desautomatizar, em suma: incomodar. Para fazê-lo, ela procura criar aberrações na linguagem o que, por sua vez, não se conseguiria fazer a partir do lugar-comum, da alegoria, da perífrase ou da metáfora, pois elas logo nos restituem à presença do objeto nomeado. Blanchot identifica distinções entre

\footnotetext{
25 Blanchot diz que Baudelaire foi o primeiro a buscar o automatismo, pois "recomenda a escrita sem arrependimentos, sem rasuras"... "para que a linguagem do sonho seja nitidamente traduzida" (Op. cit., p. 143).

26 Op. cit., p. 90-91.

27 Op. cit., p. 173.
} 
alegoria, mito e símbolo e a grande diferença seria justamente a proximidade referencial entre signo e significado. A alegoria estreita essa relação e o símbolo amplia o fosso entre eles. $^{28}$

Segundo Blanchot, o símbolo conta com ajuda da imaginação, quer dizer, a partir da inexistência da coisa, ele provoca a criação de sua imagem. "O símbolo não significa nada", no entanto, ele pode significar o que a imaginação quiser. O símbolo tem um defeito essencial que é a não coincidência plena entre a "exterioridade da imagem" e seu "conteúdo espiritual". E é essa lacuna, essa falta que torna evidente o "vazio em seu conjunto". 29 Novamente, encontramos o absoluto, o símbolo se coloca como a "experiência do nada, a busca de um absoluto negativo", 30 um todo preenchido de vazio ou um nada potencialmente significante.

É assim que o símbolo pode ser pensando como um trampolim, algo que impulsiona um salto para fora da "linguagem sob todas as suas formas". Blanchot diz que "o que ele dá a ver e a entender não é suscetível de nenhum entendimento direto, nem mesmo de qualquer entendimento", o que ele provoca é um salto para "aquilo que parece diverso de todos os sentidos possíveis". 31 Ele se constitui como uma "força de expansão infinita", como uma experiência que não se estabiliza, não se concretiza e não se unifica, que permanece inesgotável.

\section{A literatura é EXPERIÊNCIA [impossivel]}

A leitura de Benjamin sobre o surrealismo diz que este "levou a 'vida literária' até os limites extremos do possível" e explodiu seu domínio por dentro. Se a literatura explodiu, as fronteiras que definiam seu contorno voaram pelos ares e os limites de suas possibilidades ficaram abertos. Houve um contato com a morte e um renascimento.

Maurice Blanchot dirá que toda obra de arte, não apenas as surrealistas, "é a afirmação de uma experiência extrema"; 32 toda obra de arte implica esse toque nas extremidades, esse contato com o que está para além ou para fora, essa transgressão que tange o não possível ou o

\footnotetext{
28 Mito: "verdadeira presença" do significado? "pensamento" do sentido? penetração no mais rico do pensamento? (Op. cit., p. 81).

${ }^{29}$ Op. cit., p. 84.

${ }^{30}$ Idem. ibidem.

31 Blanchot. O livro por vir, p. 126-127.

32 Blanchot. O espaço literário, p. 257.
} 
desconhecido. Em sua leitura de Kafka, ele diz que o escritor sente profundamente que "a arte é relação com a morte". E, "por que a morte? Porque ela é o extremo". 33

Segundo Blanchot, morrer é o paradigma da experiência, é o acontecimento que arrebata pelo desconhecido (realmente não sabemos o que há na morte), é o abandono de sí, é a dessubjetivação do sujeito (seu desfazer-se), é o instante em que ele desaparece. A literatura como experiência carrega esse contato com o não saber e essa saída de si daquele que escreve, um entregar-se em que o Eu se neutraliza ou se desfaz num outro que é a escritura, a linguagem.

O interessante é que a experiência de morrer se coloca também como paradigma da impossibilidade. Não morro para mim. Morre-se. E mesmo minha morte não encerra a possibilidade de morrer. Há a vida que sobrevive e que ainda espera a morte sem fim. É essa impossibilidade de morte que Blanchot lê nas narrativas de Kafka, por exemplo, no personagem Gregor Samsa, de $A$ metamorfose, transformado em inseto e condenado a sobreviver como tal em um processo de decadência acelerado. E, mesmo quando ele finalmente morre, a existência continua no movimento de despertar para a vida de sua jovem irmã. "Não há nada mais apavorante em toda a novela". 34

É importante lembrar que essa leitura de Blanchot está profundamente marcada pela guerra e pelo horror dos campos de concentração, de modo que se pode contextualizar a amargura desse sentimento de "condenação à sobrevivência". A questão que se coloca diante da morte interminável dos tempos bélicos é: como a literatura é possível? Seria possível, ainda, fazer arte? E é a partir dessa operação sobre a morte que Blanchot elabora sua resposta: não, a arte não é possível, assim como a experiência da morte não o é. No entanto, é em busca dessa impossibilidade que se continua a viver. Enquanto a morte é impossível, ainda há sobrevivência. A arte é uma sobrevivência, é a criação de uma vida possível diante de uma morte inalcançável. Podemos dizer que aquela amargura inicial esboça um princípio de esperança.

Um modo mais simples de colocar tudo isso talvez seja: a literatura se percebe não mais possível em seus fundamentos modernos (afirmação do sujeito-Autor, construção de identidades, edificação de nacionalidades, instrumentalização da linguagem como representação e comunicação de sentido...) a partir do momento em que a própria modernidade também revela a falência de seus fundamentos (racionalidade, ilustração,

33 Op. cit., p. 93.

34 Op. cit., p. 17 
linearidade histórica...). Para se reabrir como possibilidade, ela precisa se suicidar, necessita se despojar, zombar de si, se arruinar, se fazer como crítica de si mesma, se expor no seu fracasso.

Essa condição remete ao "notável enigma" da literatura de que fala Blanchot: justamente quando ela se invalida, quando parece não ser mais possível ou necessária, ela vem a se tornar uma preocupação cada vez mais presente. Ao invés de ser abandonada e esquecida, ela se abandona, se desfaz de si, para ser relembrada e reativada. Blanchot o dirá nos seguintes termos:

É curioso que essa "palavra tardia, palavra sem honra que serve sobretudo aos manuais, que acompanha a marcha cada vez mais evasiva dos escritores de prosa, e designa, não a literatura, mas seus defeitos e excessos (como se estes lhe fossem essenciais), torne-se, no momento em que a contestação se faz mais severa, em que os gêneros se dissolvem e as formas se perdem, no momento em que, por um lado o mundo não tem mais necessidade de literatura, e por outro cada livro parece estranho a todos os outros e indiferente à realidade dos gêneros, no momento em que, além disso, o que parece exprimir-se nas obras não são as verdades eternas, os tipos, os caracteres, mas uma exigência que se opõe à ordem das essências, a literatura, assim contestada como atividade válida, como unidade dos gêneros, como mundo em que se abrigariam o ideal e o essencial, torne-se a preocupação, cada vez mais presente, embora dissimulada, daqueles que escrevem e, nessa preocupação, apresente-se a eles como aquilo que deve ser revelado em sua 'essência'?'35

E essa essência seria justamente o vazio da linguagem de que é feita. Por isso a literatura se move rumo ao esvaziamento, rumo à desoperação da linguagem de que já falamos. A literatura precisa se despojar dela como lei, precisa arriscá-la, torná-la inoperante, ampliar a distância entre nós e ela. Em suma: matá-la para libertá-la. É nesse sentido que Blanchot fala de "estabelecer com a morte uma relação de liberdade". ${ }^{36}$

Ele vai dizer que: se "escrever" é adequar-se às leis da linguagem, escrever passa a ser "recusar-se a 'escrever'." "Escrever sem 'escrita', levar a literatura ao ponto de ausência em que ela desaparece, em que não precisamos mais temer seus segredos que são mentiras, esse é o 'grau zero da escrita', a neutralidade que todo escritor busca, deliberadamente ou sem o saber, e que conduz alguns ao silêncio". ${ }^{37}$

Da perspectiva dos gêneros literários, o assassinato e a libertação ocorrem pela transgressão da poesia regrada, das normativas métricas, das formas do romance convencional "escrito segundo todos os usos do passado simples e da terceira pessoa".

\footnotetext{
35 Blanchot. O livro por vir, p. 292.

36 Blanchot. O espaço literário, p. 98.

37 Blanchot. O livro por vir, p. 303.
} 
Estas leis deixam de "salvar a linguagem dos perigos que a literatura a faz correr" ${ }^{38} \mathrm{E}$ a literatura passa a abalar as estruturas da linguagem. Ela passa a se fazer em estado de perda. Em estado de perda daquele que escreve. Em estado de perda da matéria com que se escreve. Em estado de perda de suas formas e certezas.

O risco a que se expõe o poeta é o do erro, o da errância, o da impossibilidade de permanecer, de se estabilizar, de se fixar. O poeta se lança no deserto da linguagem e nele se perde, se faz exilado, se desfaz de si, está fora de seu lugar natal, pertence ao estrangeiro. De modo que o exílio se apresenta como a própria condição poética. ${ }^{39}$ Diz Blanchot: "Esse exílio que é o poema faz do poeta o errante, o sempre desgarrado, aquele que é privado da presença firme e da morada verdadeira". ${ }^{40}$

O movimento e a infixidez caracterizam a própria escritura moderna. Escrever torna-se dispersão da palavra, o que por sua vez, remete a outro aspecto da literatura como experiência: o desejo de permanecer aberta como acontecimento sem fixidez no tempo (a despeito da nomeação que implica essa fixidez). Quer dizer, o texto se faz na mobilidade da escritura, a linguagem comporta certa autonomia do acaso que se manifesta de modo singular somente no instante de escrever (mesmo que haja uma intenção prévia de como se vai formular a frase, é ao formulá-la que ela acontece). Ao ser escrita, ao ser nomeada a frase, há algo que se fixa.

No entanto, o texto quer continuar aberto, exposto ao acaso da leitura. Ele vai se refazer nessa operação de leitura. ${ }^{41}$ Como diria a narradora de Agua viva (de Clarice): "Você que me lê que me ajude a nascer". Por mais data de nascimento que tenha um poema, ele voltará a nascer a cada leitura. Nesse sentido, diz Blanchot: "um poema não é sem data, porém, apesar da sua data, ele está sempre por vir". ${ }^{42}$ E esse devir em aberto tem a ver com a multiplicidade de significações de um texto, com a inexistência de uma totalidade ou de um significado fechado e definitivo.

No plano da escritura, o exercício explorado passa a ser o do espaçamento. Blanchot diz que em Valéry e Kafka o que importa não é a obra final edificada e sim o

\footnotetext{
38 Op. cit., p. 298-299.

39 Segundo Blanchot, denominada por Saint-John Perse em um de seus poemas.

40 Blanchot. O espaço literário, p. 259-260.

${ }^{41}$ Blanchot fala da Leitura como operação em: O livro por vir, p. 357. "Ler seria, pois, não escrever de novo o livro, mas fazer com que o livro se escreva ou seja escrito - desta vez sem a intermediação do escritor, sem ninguém que o escreva" ( $O$ espaço literário, p. 209).

42 Blanchot. A parte do fogo, p. 113.
} 
movimento que conduz à ela. ${ }^{43}$ Como nos exercícios da arte abstrata em que se procura desvincular a pintura da necessidade de figurar objetos. O que se explora é o trabalho da criação em processo: a cor, a textura, o movimento, a composição singular...

Mallarmé continua sendo o grande exemplo de análise para Blanchot. Fazendo uma comparação justamente com a pintura, ele diz sobre o escritor que "não é desses que, para pintar um objeto, o incorporam a seu quadro". Quer dizer, Mallarmé, ao escrever, foge da figuração. A palavra não importa pelo objeto ao qual se refere; ela se afasta dele e, de sua liberdade de significar, se abre para um devir rítmico, ou seja, para um deslocamento no espaço do poema em que entra em relação com outras palavras. O que está em jogo é a trajetória ritmada, o modo pelo qual as palavras se espaçam e se disseminam, criando uma constelação. Valéry diz, a respeito de Mallarmé, que ele "elevou 'enfim uma página à potência de um céu estrelado'." ${ }^{4}$ Joubert, que Blanchot vê como um anúncio da poesia de Mallarmé, já dissera: “"Eu gostaria que os pensamentos se sucedessem num livro como os astros no céu, com ordem, com harmonia, mas à vontade e com intervalos, sem se tocarem, sem se confundirem'., 45

Blanchot chama esse movimento de "espaçamento cósmico" e diz que uma das soluções encontradas pela poesia para promovê-lo é a música. “'É necessário que os pensamentos se sucedam e se liguem como os sons na música, somente por sua relação harmonia - e não como os elos de uma cadeia'." Mallarmé busca criar, em "um lance de dados”, um poema em que “"as palavras - [...] - reflitam-se umas nas outras até parecerem não ter mais sua cor própria, mas serem somente as transições de uma escala musical.."46

O poema se escreve como uma partitura. As palavras não significam, elas vibram e ressoam. A linguagem poética se apresenta como "a maravilha de transpor um fato natural para seu quase desaparecimento vibratório". ${ }^{47}$ Clarice Lispector continua nos oferecendo exemplos quando propõe que a leitura seja um exercício de escuta da vibração da palavra. Um exercício que se faz com o corpo inteiro e que desloca a leitura da necessidade de compreensão racional: "Não se compreende música: ouve-se", diz a narradora de Água viva. E, logo: “Ouve-me então com teu corpo inteiro".

\footnotetext{
${ }^{43}$ Blanchot. O livro por vir, p. 291.

${ }^{44}$ Op. cit., p. 85.

45 Idem. ibidem.

46 Op. cit., p. 329.

47 Op. cit., p. 330.
} 
Explorar a linguagem fora do discurso inteligível, desfazê-la enquanto tal, essa seria a experiência-limite provocada pela literatura. Ela é um desdobramento da experiêncialimite que surge como resposta ao homem quando decide se "pôr radicalmente em questão"; uma decisão que "exprime a impossibilidade de jamais deter-se em qualquer consolação ou em qualquer verdade que seja". ${ }^{48}$ A Literatura aberta a essa experiência é uma literatura que não se deixa estabilizar, que não se fecha em uma normativa poética e que não encerra o significado.

A experiência-limite implica ultrapassar o possível, implica encontrar os meios de falar quando falar não parece mais uma possibilidade; ela é a sobrevida que sucede à morte: "é a experiência daquilo que existe fora de tudo, quando o tudo exclui todo exterior, daquilo que falta alcançar, quando tudo está alcançado, e que falta conhecer, quando tudo é conhecido: o próprio inacessível, o próprio desconhecido". ${ }^{49}$ Ela é a falta, é o excedente do ABSOLUTO, a gota que faz transbordar a totalidade e que a anula enquanto tal: se pode haver essa gota a mais, então o todo não estava completo.

O problema que se evidencia é "como o absoluto pode ainda ser superado?" Uma pergunta que, no plano ético, remete ao gesto político de contestar as pretensões de consumação de uma completude do homem do Humanismo. Essa concepção de homem e de civilidade pode ser colocada em questão? Blanchot pergunta:

Como o homem, tendo atingido o cume graças à sua ação, poderia - ele o universal, ele o eterno, sempre consumando-se e sempre consumado, e repetindo-se num Discurso que nada faz a não ser falar-se sem fim - não ater-se a essa suficiência e, como tal, pôr-se em questão? Falando com propriedade, não pode. E no entanto a experiência interior exige esse acontecimento que não pertence à possibilidade. ${ }^{50}$

Trata-se de perceber a incompletude e de saber-se em busca de uma completude inalcançável; trata-se de reconhecer que sempre haverá uma falta, mas que sempre há um algo a mais, uma potência de superação em que se transpõe o intransponível - e essa é a experiência-limite, na arte, na vida, no pensamento: “o pensamento pensa aquilo que não se deixa pensar!". ${ }^{51}$

Enfrentar o impossível para refazer o possível. Encarar a morte para deixar renascer a vida. Blanchot diz que "Todo homem procura morrer no mundo, quereria morrer do

\footnotetext{
48 Blanchot. A conversa infinita 2, p. 185.

49 Op. cit, p. 187.

50 Op. cit., p. 189-190.

51 Op. cit., p. 193.
} 
mundo e para ele \{quem nunca quis um dia morrer DO mundo? já diria um velho sábio: "pare o mundo que eu quero descer"\}. Nessa perspectiva, "morrer é ir ao encontro da liberdade que me torna livre do ser, da separação decidida que me permite escapar ao ser pelo desafio, a luta, a ação, o trabalho, e superar-me ao passar para o mundo dos outros. Eu sou, eu sou somente porque fiz do não ser o meu poder, porque posso não ser". ${ }^{2}$ Há algo como um jogo de se fazer outro para se perceber.

É interessante pensar que, por um lado, podemos querer morrer DO mundo porque não o suportamos, mas também pode ser: "mate-me agora" porque cheguei ao auge, porque vivi o êxtase, o máximo. Morro agora e morro plena, morro satisfeita. Abre-se uma zona limiar em que a morte se confunde com o gozo pleno da vida e é nessas aberturas de ciclo - morte-vida/presença-ausência - que opera a lógica - quase matemática - de Blanchot; justamente nesses espaços em que se desfazem as oposições e se percebem os contatos.

Com essas formulações paradoxais se propõe uma alteração na percepção: se a morte se vê exclusivamente como a oposição da vida, não se percebe que uma engendra a outra. Se a doxa, se o "senso-comum", diz que a palavra é a presentificação da coisa, essa lógica operada por Blanchot fará perceber que a palavra é a ausência da coisa.

E qual é a ausência absoluta? O silêncio. O silêncio é o absoluto. Portanto, se a palavra é ausência, sua essência é o silêncio: esse é o jogo dedutivo da análise. Cabe perguntar: de que nos vale jogar esse jogo de desfazer e refazer a lógica? Ou de esvaziar a palavra com a palavra? O jogo vale por si mesmo? Sim, ele reivindica essa autonomia. Jogase por jogar; ele é justamente o que escapa à utilidade ou à necessidade. Mas jogar é se deslocar nesse tempo em que nos tornamos personagens, adversários, crianças; é criar nele um outro do mundo e, ao voltar ao mundo, percebê-lo de outro modo. Se rodopiar de olhos fechados, ao abri-los, perceberei algo diverso em meu entorno. E esse já é um por quê do jogo. Sua relevância é evidente, porém nem tão evidente... É importante que seja exposta essa evidência, porque se corre o risco, sim, de viver uma vida inteira sem se permitir jogar, sem se permitir perceber o mundo de um modo diverso. E o que a arte faz é um convite ao jogo, ao jogo como experiência [que é única autoridade de si mesma].

AQUE VEM A PALAVRA?

52 Blanchot. O espaço literário, p. 178-179. 
A palavra poética vem para nos fazer experimentar o estar no mundo. E, para experimentá-lo, precisamos sair de nós mesmos, entrar em contato com o fora, desnudarnos e sentir o atrito do vento na pele. Há duas dimensões dessa experiência: a do contato com o desconhecido e a da sensação.

Ao nos instigar a perceber o que há para lá do conhecido, do consagrado ou do consabido a arte provoca um salto onde o impossível se torna recomeço ou onde a impotência se torna fecunda. Blanchot diz que Rimbaud exige da poesia que ela "ajude o homem a ir a algum lugar, a ser mais do que ele próprio, a ver mais do que pode ver, a conhecer o que não pode conhecer". ${ }^{53}$ A frase de Paul Klee ficou consagrada: "O pintor não representa o visível, ele torna visível”. E Gilles Deleuze completou: “é a mesma coisa com o músico. Ele torna audíveis forças que não são audíveis". ${ }^{44}$ Assim como o filósofo, "que torna pensáveis forças que não são pensáveis". Essa é a característica da criação: fazer do inexistente o ponto de partida. Breton destaca em seu manifesto: “o nada não é impossível para quem sabe ousar". Quer dizer: justamente onde não há, criar. Fazer existir uma sobrevivência, abrir novos devires, perceber que o último ponto do abismo se abre para o mar e para o ar infinitos.

Blanchot dirá que: "Por existir o poema o futuro é possível”, porque “o poema é esse movimento em direção ao que não é", 55 ele é a abertura de caminhos acessíveis para fins inacessíveis. Esse é um forte potencial político da imaginação: fazer transbordar o existente e dar vida ao inexistente. Com isso, a arte gera um movimento sem fim de superação; não há totalidade ou finalidade, há devir e processo.

É assim que Blanchot define $o$ Aleph, o infinito literário, como "o perigoso poder de ir em direção àquilo que é, pela infinita multiplicidade do imaginário" ${ }^{56}$ Nesse espaço do imaginário pode-se tudo, podem-se criar novos mundos, outros do mundo. Blanchot pergunta:

O que pode um autor? Primeiro, tudo: ele está agrilhoado, a escravidão o pressiona, mas, se ele encontrar, para escrever, alguns momentos de liberdade, ei-lo livre para criar um mundo sem escravo, um mundo onde o escravo, agora senhor, instala a nova lei; assim, escrevendo, o

\footnotetext{
53 Blanchot. A parte do fogo, p. 152.

${ }^{54}$ Deleuze, L'abécédaire.

55 Op. cit., p. 105.

${ }^{56}$ Blanchot. O livro por vir, p. 140.
} 
homem acorrentado obtém imediatamente a liberdade para ele e para o mundo; nega tudo o que ele é para se tornar tudo o que ele não é..$^{57}$

Nesse espaço criado com a palavra, a "linguagem não é um poder", 58 ela se liberta para se tornar mais potente. A palavra se liberta de sua necessidade de figurar, a narrativa se despoja da obrigação de se fazer inteligível, de fazer sentido.

E por que esse desprezo ao sentido? Por que esse desejo de se fazer sentir e não de fazer sentido? Por que a vontade de incomodar, estremecer, desestabilizar e não de explicar ou de dar coesão? Há uma nota em $O$ espaço literário de que gosto muito. Ela diz:

Quanto mais o mundo se afirma como futuro e dia pleno da verdade onde tudo terá valor, onde tudo conterá sentido, onde o todo se realizará sob o domínio do homem e para seu uso, mais parece que a arte deve descer para esse ponto onde nada ainda tem sentido, mais importa que ela mantenha o movimento, a insegurança e o infortúnio do que escapa à toda a apreensão e a todo o fim. O artista e o poeta como que receberam a missão de nos recordar obstinadamente o erro, de nos voltarmos para esse espaço em que tudo o que nos propomos, tudo o que adquirimos, tudo o que somos, tudo o que se abre na terra e no céu, retorna ao insignificante, onde aquilo que se aborda é o não sério e o não verdadeiro, como se talvez brotasse aí a fonte de toda a autenticidade. ${ }^{59}$

O não fazer sentido se coloca como modo de provocar o abalo de certezas e verdades consolidadas. É ao desautomatizar o uso e a compreensão da linguagem que a literatura abre para a sensação do estar no mundo. É ao subverter o mundo que a arte provoca a percepção do mundo.

Gilles Deleuze diz que "o artista é uma pessoa que cria perceptos: "conjuntos de percepções e sensações que vão além daqueles que as sentem". ${ }^{60}$ Uma variedade de sensações visuais, auditivas e quase gustativas que se podem sentir na leitura de um texto e que adquirem uma independência radical em relação àquele que as sentiu. Para Deleuze, a arte procura dar uma duração ou uma eternidade a um complexo de sensações. Victor Chklovski já dissera (em 1917, “A arte como procedimento”) que é “para devolver a sensação de vida, para sentir os objetos, para provar que pedra é pedra" que "existe o que se chama arte".

\footnotetext{
${ }^{57}$ Blanchot. A parte do fogo, p. 304.

58 “A linguagem é uma legislação, a língua é seu código. Não vemos o poder que reside na língua, porque esquecemos que toda língua é uma classificação, e que toda classificação é opressiva: ordo quer dizer, ao mesmo tempo, repartição e cominação. Jakobson mostrou que um idioma se define menos pelo que ele permite dizer, do que por aquilo que ele obriga a dizer" (Barthes. Aula, p. 11).

${ }^{59}$ Blanchot. O espaço literário, p. 270-271.

${ }^{60} \mathrm{G}$. Deleuze, L'abécédaire.
} 
Será essa uma gota de entusiasmo? A coragem de criar o novo de novo, quando todas as possibilidades do criado parecem esgotadas? Inspirar e se dispor a uma nova tentativa fora de todo o sentido convencionado? Deixar-se arrebatar por uma experiência inútil em um mundo eminentemente utilitário? Provocar as sensações do corpo em um mundo em que o corpo se quer anestesiado? O entusiasmo de escrever o que resiste a ser escrito.

\section{REFERÊNCIAS}

Barthes, Roland. Aula. Tradução de Leyla Perrone-Moisés. São Paulo: Cultrix, 1988. . Novos ensaios críticos seguidos de O Grau zero da escritura. Tradução de Heloysa de Lima Dantas e Anne Arnichand e Álvaro Lorencini. São Paulo: Cultrix, 1993.

Bataille, Georges. A experiência interior. Tradução de Celso L. Coutinho, Magali Montagné e Antonio Ceschin. São Paulo: Ática, 1992.

Blanchot, Maurice. O espaço literário. Tradução de Álvaro Cabral. Rio de Janeiro: Rocco, 2011.

O livro por vir. Tradução de Leyla Perrone-Moisés. São Paulo: Martins Fontes, 2005. - A conversa infinita 2: a experiência limite. Tradução de João Moura Jr. SP: Escuta, 2007.

- A parte do fogo. Tradução de Ana Maria Scherer. Rio de Janeiro: Rocco, 1997.

Chklovski, Vitor. "A arte como procedimento". Em: EIKHENBAUM, B. et al. Teoria da Literatura (Formalistas russos). Tradução de Ana M. Ribeiro et al. Porto Alegre: Globo, 1971.

Deleuze, Gilles. L'abécédaire. (Em DVD). Paris: Montparnasse. Diretor: Pierre-André Boutang. Entrevistadora: Claire Parnet, 2004.

Lispector, Clarice. Água viva. Rio de Janeiro: Rocco, 1998. - A paixão segundo G.H. Rio de Janeiro: Rocco, 2009. Um Sopro de Vida. Pulsações. Rio de Janeiro: Nova Fronteira, 1978. 